\author{
Sławomir Magala \\ Rotterdam School of Management, Erasmus University Rotterdam, \\ Uniwersytet Jagielloński
}

\title{
Rozmowy czasem kontrolowane (czyli jakie media sq̨ na czasie?)
}

\begin{abstract}
Streszczenie
W zapośredniczonym medialnie dyskursie publicznym pełno czarnych dziur zapowiadanych przez zasadę nieoznaczoności. Przyszłe uydarzenia są równie nieprzewidywalne co przyszła wielowymiarowa arbitralność uróbelka powieszonego na drzewie w „Kosmosie” Gombrowicza. Witajcie u społeczeństwie sieci, witaj homo informaticus, witaj digitalna infosfero z transhumanistycznym pogłosem mediów społecznościouych. METOO; kto da więcej?
\end{abstract}

Słowa kluczowe: media społecznościowe, homo informaticus, digitalna infosfera, polityczna poprawność.

\section{Some conversations are recorded (which media are in?)}

\begin{abstract}
Media mediated public discourse displays black holes predicted by the uncertainty principle. Future events are as unpredictable as a sparrow hanging on a branch in Witold Gombrowicz's 'Cosmos'. Welcome to the network society, to homo informaticus, to a digital infosphere with transhumanist echo of social media. 'METOO', anyone?
\end{abstract}

Keywords: social media, homo informaticus, digital infosphere, political correctness.

\section{Preambuła filozoficzno-demograficzna}

O czym powinniśmy wiedzieć? O tym, co może nam być potrzebne w życiu codziennym, w realizacji naszych zamiarów. Skąd się o tym dowiadywać? Ze szkól, z gazet, z rozmów z dobrze poinformowanymi ludźmi? Wygodniej sięgnąć po osobisty telefon komorkówy. O co zapytamy nasze małe zuierciadełko, chodzące z nami po gościńcach epoki? O to, o czym wiemy, że chcemy się tego dowiedzieć. I o to, co będzie nam potrzebne, ale jeszcze się tego nie domyślamy. O cokolwiek, co może stać się treścią naszej wiedzy, której formy oraz treści staramy się zobiektywizować, materialnie utrwalić. Uzgadniamy je, ale nie wiemy z góry, co z tego uzgadniania wyniknie. Flogiston się nie ostał, struny i spiny - tak. Uzgadniamy po to, żeby jak najpeuniej dowiadywać się jeszcze więcej i jeszcze szybciej - ale i po to, żeby inni też mogli się dowiadywać już bez naszej bezpośredniej pomocy. O czym jednak zazwyczaj chcemy się czegoś dowiedzieć? 
O czymkolwiek, czym się zainteresujemy na tyle, by otoczyć to rusztowaniami badaczy, poddać obserwacji, poobracać na uszystkie strony. Poza tym nie jest sprawą obojętną, co z tą wiedzą zrobimy później. Zacznijmy jednak od podwalin, założeń, przesłanek, rusztowań. Media to nośniki informacji, instrumenty kształtowania wiedzy, narzędzia jej stosowania w praktyce (the proof the the pudding...).

Ale jakie media? Młode pokolenie Holendrów, ale także Włochów, Polaków, Niemców, Francuzów, Amerykanów nie poddaje się jednej formule (mimo prób wpakowania ich uszystkich do pudła z napisem „milenialsi” - od słowa „milenium”). Młodzi Holendrzy, których badali eksperci na zlecenie organu koordynującego i nadzorującego media publiczne $\mathrm{w}$ interesie demokratycznej równowagi u Królestuie Holandii (stichting NPO, czyli fundacja Nederlandse Publieke Omroep) zostali przez media społecznościowe oraz coraz bardziej rozdrobnione media tradycyjne poszatkowani na coraz mniejsze segmenty. Dlaczego? Przede uszystkim z powodu szybkości (telefon komórkowy wydobywam z kieszeni natychmiast i gdziekolwiek, nie muszę biec po gazetę do kiosku ani zasiadać przed telewizorem) i wygody (wybieram tylko te wiadomości, które są mi akurat potrzebne, reszta może sobie wisieć w wirtualnych wiadomościach możliuych).

Wśród najmłodszej grupy badanych, czyli nastolatków od 13. do 19. roku życia przeważają media społecznościowe, na przykład WhatsApp, Facebook, Twitter, Snapchat albo Instagram. Poświęcają im średnio 77 minut dziennie. W tym czasie ani nie nawiązują kontaktów twarzą w twarz, ani nie oglądają telewizji, ani nie czytają gazet. Dla młodych dorosłych (od 20. do 34. roku życia) jest to już niewiele ponad pół godziny dziennie. Tyle poświęcają dziennie uwagi, dzieląc ją między wcześniej wymienione media społecznościowe, natomiast telewizja (a także radio, zwłaszcza w samochodzie) też stopniowo uychodzi na swoje. $Z$ uiekiem rośnie więc potrzeba nieco spokojniejszej refleksji, dostępu do wiedzy mniej uyrywkowej, doraźnej, powierzchownej? Im starsza grupa docelowa, tym mniejsze zainteresowanie mediami społecznościowymi. W grupie od 35. do 49. roku życia to już niecałe pół godziny, a dla ludzi w wieku od 50 do 64 lat to już tylko 25 minut. Badano też częstotliwość oglądania krótkich filmów wideo w serwisie YouTube. I znów, nastolatki poświęcają na to średnio 15 minut dziennie, młodzi dorośli 6 minut, grupa 35-49 lat znajduje tylko 3 minuty czasu na taką czynność, natomiast $w$ grupie powyżej 50. roku życia prawie nie ogląda się filmów na YouTube.

Skutki tego pokoleniowego rozdrobnienia zbiorowości uyborców dają już o sobie znać. We Włoszech komik Beppe Grillo mobilizuje uyborców dzięki mediom społecznościouym, podczas gdy socjaliści oraz Silvio Berlusconi polegają głównie na środkach masowego przekazu, takich jak kanały telewizyjne, radiostacje, grupy dzienników oraz tygodników. Po marcouych wyborach parlamentarnych w 2018 roku we Włoszech można się będzie przekonać o tym, czy popierany przez młodszych wyborców antyestabliszmentowy Beppe Grillo (realizator idei nowych ruchów społecznych Manuela Castellsa z Barcelony, zbliżony nieco do ruchu Kukiz 15 w Polsce) potrafi się zmierzyć z okopanymi $\mathrm{w}$ tradycyjnych środkach masowego przekazu socjalistami albo 
Berlusconim i jego koalicjantami. W chwili gdy piszę te słowa, od uyborów dzielą nas jeszcze dwa miesiące, więc wysnuwanie uniosków byłoby przedwczesne.

Jakie założenia powinniśmy ugruntować, zanim wysnujemy na ich podstawie w miarę niezawodne unioski? Pytanie nie jest tylko powtórzeniem znanego (choć bynajmniej nietrywialnego) pytania o to, czy najpierw była kura, która później zniosła jajko, czy właśnie jajko, z którego później wykluło się kurczę, które wyrosło na kurę. W sprawie mediów można zapytać, czy najpierw była treść, którą chciano przekazać, szukając środka przekazu, czy też najpierw pojawił się środek przekazu, a potem zaczęto się zastanawiać, jakie treści za jego pomocą najlepiej byłoby przekazywać. W innej wersji: czy najpierw były media, które rozpouszechniały wizje świata społecznego, czy najpierw był świat społeczny, który wykształcił środki upowszechniania wiedzy o sobie? Nie można liczyć na niepodważalny autorytet przyrody, materialnej rzeczy samej. Obraz uszechświata, jaki się wyłania z badań kosmologów, astronomów albo fizyków, pełen jest wielkich wybuchów, czarnych dziur, przenikających się nawzajem sygnałów, antymaterii oraz skręconych (a nie wyprostowanych) jak struna mikrocząsteczek udających fale, fal udających pola, pól udających energię. Czy rozumienie Alberta Einsteina wpływa na interpretacje Marshalla McLuhana? Albo na odwrót, czy nowe odczytanie proroctw McLuhana upłynie na zrozumienie Einsteina i Maxa Plancka, Erwina Schrödingera i Ludwiga Boltzmana?

Takie pytania mogą się uydawać nadmiernie filozoficzne, metafizyczne, ontologiczne, wydumane. Ale nie są. Najnowszy kryzys finansoury roku 2008 wyraźnie potwierdził upadek autorytetu ekspertów, zarówno republikańskich, jak i demokratycznych. Nikt spośród uznanych ekspertów nie rozumie, dlaczego USA obecnie, a więc pod rządami Donalda Trumpa prosperują (a pod rządami lubianego przez media Baracka Obamy kulały), dlaczego kwitnie polska gospodarka pod rządami PiS (a pod rządami lubianej przez media mainstreamu koalicji PO z PSL kulała). Zatem pytania o to, jak należy rozumieć splątane procesy interakcji powiązanych z komunikacjami na płaszczyznach gier ekonomicznych, politycznych albo kulturalnych, nie są nadmiernie filozoficzne albo metafizyczne. Byłyby, gdybyśmy uznali, że nasze poznanie jest niedoskonałe tylko dlatego, że wciąż doskonalimy narzędzia, a więc że z czasem media się o wynikach stosowania tych udoskonalonych narzędzi dowiedzą i ogłoszą, jaki świat jest dokładnie - co do joty, zausze i uszędzie. Wtedy mnożenie bytów oraz wydumanych pytań byłoby niepotrzebnym opóźnianiem walca rozumu budującego autostradę do pełnej wiedzy. Ale do uznania, że jesteśmy na jedynie słusznej drodze do poznania całej prawdy i tylko prawdy o uszechświecie mamy coraz dalej.

Alan Greenspan nie miał pojęcia, dlaczego nastąpił krach finansouy, jego następca Ben Bernanke nie był w stanie odgadnąć, dlaczego nie pomógł gigantyczny zastrzyk finansowy ze strony państwa, następczyni Bernankego, Janet Yellen, nie potrafi przewidzieć możliuych kryzysów w przyszłości. Niektórzy obserwatorzy procesów gospodarczych zapytują nawet z troską w głosie „czy na pewno leci z nami pilot?”. W tym uszechświecie wiedzy niepewnej, niewystarczającej jako ubezpieczenie od 
ryzyka, mnożenie bytów medialnych bynajmniej sprawy nie ułatwia. Powszechnie przyjmuje się, za fizykami oraz kosmologami, że najuażniejsze trudności poznaucze wynikają z samej natury procesów przyrodniczych, że sama przyroda utrudnia, ba, wręcz uniemożliwia teoretycznie nieskończony rozwój wiedzy o tym, co i jak jest, istnieje, faktycznie, rzeczywiście, co stanowi rzeczywistość ${ }^{1}$.

\section{Odbiorcy, nadawcy oraz to, co przekazywane}

Jednakże to nie przyroda (przedstawiana czasami jako Natura z dużej litery N) jest głóuną przeszkodą w zrozumieniu, o co chodzi w komunikacji zapośredniczonej medialnie. Uczestnicy komunikacji, zarówno nadawcy, jak i odbiorcy (zwłaszcza odbiorcy, bo oni mają większy upłyu na sens komunikacji) nie są bynajmniej określeni raz na zausze i wszędzie ponad uszelką wątpliwość metodologiczną, ontologiczną, metafizyczną. Nadeszła era - jak twierdzą niektórzy prorocy nowej sytuacji komunikacyjnej - homo informaticus, czyli zindywidualizowanych komunikacyjnie jednostek masowo korzystających ze spersonalizowanych technik/technologii informacyjno-komunikacyjnych ${ }^{2}$.

Po pierwsze, uspółczesne dyskusje na temat środków masowego przekazu nie dotyczą przeważnie mas jako milionowych rzesz prawdziuych żyuych ludzi. Masy istnieją w nich jako statystyczne dane dotyczące oglądalności albo osłuchania, albo czytelnictwa przypisywane zbiorowiskom żywych ludzi. Masy istnieją w nich jako agregaty jednostek gromadzonych przez specjalistów od masowania danych w grupy rzekomo podatne na sygnały wysyłane przez „wielkich braci”. To pierusze uproszczenie. Statystyka, czyli - jak mawiał Stanisław Lem „sadystyka” - zastępuje rzeczywistość. Jeśli masy rozpadną się i zreorganizują na nowo, na przykład w ruch „oburzonych” w Hiszpanii, w ruch „Okupujcie Wall Street”, albo w ruch Tea Party w USA czy ruchy arabskiej wiosny w Egipcie albo Tunezji, to już inaczej zareagują na autorytety, inaczej potraktują polityków, a przekaz środków masouego przekazu spotka się z przyjęciem zupełnie innym niż oczekiwały władze (albo zawodowi obsługiwacze mediów).

Drugie uproszczenie dotyczy środków przekazu stosowanych do artykulacji poglądów udostępnianych w przestrzeni publicznej dopuszczalnym (przysiadalnym, jak mawia Marcin Świetlicki) odbiorcom. Środki istnieją w nich jako kolosy na glinianych nogach popularności. Jako zreifikowane, wielkie konglomeraty korporacji - na przykład stajnia Springera, wylęgarnia TVN, siatka Sorosa, lecz także fundacja ojca Rydzyka, korporacja CNN, jej konkurentka Fox itd. Środki przekazu są uyobrażalne, przeważnie jako polityczne klocki lego składające się na wielkie bloki masouego rażenia ludzi - te bloki tradycyjnie nazywamy „prasą” (do czytania), „telewizją” (do oglądania i słuchania), stronami internetowymi (do podglądania, podczytywania, podsłuchiwania) - takimi

\footnotetext{
${ }^{1}$ Por. np. M. Gleiser, The Island of Knowledge. The Limits of Science and the Search for Meaning, Basic Books, New York 2014.

${ }^{2}$ M. Gurri, The Revolt of the Public (and the crisis of authority in the new millennium), Kindle Books 2014.
} 
jak przykładowo „onet” (własność Springera, który reprezentuje interesy niemieckie w Polsce, choć jest ułasnością szwajcarsko-niemiecką), ,politico” (literacki przedstawiciel amerykańskiej centrolewicy liberalnej u sensie „liberal arts college”, niekoniecznie politycznego liberalizmu) czy „pudelek” (pudelek jest jak koń u księdza Benedykta Chmielouskiego w „Nowych Atenach wszelkiej scjencyji pełnych” - jaki jest, każdy widzi). Gromadzenie środków masowego przekazu w klocki oraz bloki to uproszczenie, bo uszystkie poszczególne środki (np. tygodnik „Wprost” albo „Telewizja Republika”) ewoluują w konstelacjach i kontekstach, które warto poznać, aby środki zrozumieć.

Po trzecie, przekaz to nie list $w$ butelce rzucany na fale radiowe albo inne nośniki naszych digitalnie zaszyfrowanych konwersacji. Przekaz to coś w rodzaju oświadczyn składanych za pośrednictuem wielu swatek, swatów oraz pośredników i tłumaczy. To negocjowalna propozycja składana pełnokrwistym obywatelom; czynnym, wrażliwym, zorientowanym w największych nierównościach i niesprawiedliwościach relacji/ interakcji oraz poruszanym obywatelską pasją odbiorco-współtwórców komunikacji. Obywatele, czyli „,współkomunikanci” mogą ośuiadczyny przyjąć, mogą je odrzucić, mogą wyjaśnić dlaczego, mogą zdanie zmienić. Dotyczy to nawet przekazu na tyle zindywidualizowanego, że nadawcy oraz kontrolerzy pozwalają sobie nazwać przekaźniki „mediami społecznościouymi”. Ale reakcje zuykłych ludzi, faktycznie istniejących jednostek, też mogą być „fake’ami”, czyli podróbkami, fałszywkami. Mogą mianowicie należeć do światów urojonych przez firmy manipulacyjne. Udają one uspólnoty komunikantów, ale są w gruncie rzeczy wioskami Potiomkina stawianymi nie na drodze carycy, ale na skrzyżowaniach światłowodów, którymi mkną komunikacje „globalnego" megaspołeczeństua. Wpływ spontanicznego głosu internautów na rzeczywistość jako taką jest dzięki wioskom Potiomkinouskim (nie przypadkiem celują w tym Rosjanie) ograniczany, a następnie zastępowany masowym „trollowaniem” oraz ideologicznym przygotowywaniem gruntu dla czarodziei z krainy wiecznego uśmiechu, czyli pi-aru.

Dodajmy jedno ostrzeżenie. Takie podejście - wypowiedzi o środkach masowej komunikacji, które zakładają określonego oraz przewidywalnego odbiorcę oraz wyraźnego w świadomości odbiorców nadawcę - pozwala patrzeć na media, jakby to były proste przeká́niki raportów z rzeczywistości, które mają informować i tylko informować (albo dezinformować). Takie uproszczone, ale niekwestionowane w mainstreamie podejście pozwala w tajemniczy sposób pomijać najistotniejsze ułaściuości współczesnej komunikacji społecznej, która zaczyna się na długo, zanim jeszcze odbiorcę zaatakuje jakakolwiek informacja. Chodzi o wprowadzenie do atmosfery komunikacji substancji (porównywalnych tylko z gazami bojowymi) mających wywołać uprzedzenia oraz pogłębić przesądy, żeby informacja padała na podatny grunt. Niezrozumienie nieustannego kreowania przesądów i uprzedzeń z kolei utrudnia zrozumienie najistotniejszych składników nakładającej się na nie naszej teraźniejszej rozmowy ludzkości, czasami zwanej na przykład dyskursem publicznym. Najistotniejszą towarzyszką tej rozmowy jest ułaściwość, którą można nazuać nieprzewidywalnością naszej przyszłej arbitralności. Nieprzewidywalnością wielowymiarową. Niektórzy autorzy mówią 
o społeczeństwie sieci (Castells ${ }^{3}$ ), niektórzy o homo informaticus (Gurri). Jeszcze inni uspominają o przejściu z alfabetycznej do digitalnej infosfery z możliwymi transhumanistycznymi, czyli - hm - postludzkimi efektami, oraz o coraz większej autonomizacji coraz bardziej połączonych komunikacyjnie, ale rozdzielanych i fragmentaryzowanych interakcyjnie jednostek:

Problem wygląda tak: jak do tego doszło, że w pewnych warunkach pozłączane znaki prowadzą do narodzin znaczenia? Jak do tego doszło, że w pewnych warunkach pozłączane okoliczności stają się historią? A pozłączane spostrzeżenia stają się rzeczywistością? Witold Gombrowicz sugeruje, że rzeczywistość uynika z obsesji ${ }^{4}$.

Franco „Bifo” Berardi powołuje się naturalnie na „Kosmos” Witolda Gombrowicza. Ale „Kosmos”, mimo inteligentnej ekranizacji filmowej, mógłby zaistnieć w mediach społecznościowych, a więc także w śuiadomości młodszego pokolenia dopiero w chuili, w której arbitralność wróbelka powieszonego na drzewie skojarzyłaby się licealistom z listą lektur obowiązkouych albo decyzjami bohateróu Krzemowej Doliny, by postawić na osobiste, kieszonkowe, komputerowe, połączone satelitarnie sekretarki dla każdego. Dopóki się nie skojarzy, Gombrowicz, podobnie jak Vladimir Nabokov, pozostanie ulubieńcem akademickich oraz intelektualnych osiedli zamkniętych. Oligarchie jeszcze mogą go traktować jako proroka z marginesu. Ale już powinny rozumieć zagrożenie ze strony powieszonego za nóżkę na gałęzi drzewa wróbelka. Autorytet staje się róunie arbitralny w oczach obserwatorów, co ów wróbelek. Kampanie reklamowe bądź propagandowe albo lansowanie nowych wizji rzeczywistości przez samozwańcze oligarchie mogą się skończyć dla nich źle.

Najnowszym przykładem jest nielegalna z punktu widzenia prawnych uzgodnień państw członkowskich oligarchia władz Unii Europejskiej. Ale oligarchia ponadnarodowych korporacji w sprawie genetycznie manipulowanej żywności to inny, równie niedawny przykład nadużywania struktur uładzy do podważania demokracji. Takie próby podważania demokracji, jej zastępowania autorytetem eksperta, są dzisiaj szybciej wykrywalne (a często wręcz faktycznie wykrywane), a ich obrona, mimo znacznych sił i środków, jest coraz mniej skuteczna. Sejsmologowie włoscy oświadczyli - na sześć dni przed trzęsieniem ziemi, które zrównało w 2009 roku z ziemią miasteczko L’Aquila, zabijając 300 osób - że poważniejsze zagrożenie sejsmiczne jest u gruncie rzeczy wykluczone. Nic dziunego, że siedmiu członkom włoskiej Narodowej Komisji do Ostrzegania i Zapobiegania Klęskom Naturalnym postawiono zarzut rozpouszechniania niedokładnych, niepełnych oraz sprzecznych informacji, dotyczących pieruszych ustrząsów, przed głównym trzęsieniem z 6 kuietnia 2009 roku. Ostatecznie sąd skazał w 2012 roku sześciu naukouców i jednego urzędnika państwowego na kary sześciu lat więzienia. Ale w roku 2014 wyrok uchylono, dopatrując się głóunych przyczyn

\footnotetext{
${ }^{3}$ M. Castells, The Rise of the Network Society, The Information Age: Economy, Society and Culture, vol. I, Blackwell, Cambridge MA \& Oxford, UK 1996.

${ }^{4}$ F. „Bifo”, Berardi, AND. Phenomenology of the End. Sensibility and Connective Mutation, Semiotext(e), South Pasadena, CA 2015, s. 14.
} 
tragedii nie w lekceważeniu pieruszych ustrząsów przez sejsmologów, ale u niskiej jakości materiałów budowlanych użytych do postawienia budynków, w których zginęło najwięcej ludzi. Kasta sędziouska broniąca kasty akademickiej? A może po prostu deformacja informacji w mediach. Gdyby udało się im przekazać wątpliwości uczonych, ich niepewność co do diagnozy, może władze zareagowałyby inaczej, a do procesu by nie doszło? Media sterowały skupianiem publicznej uwagi. Media donosiły o katastrofie na pierwszych stronach. O wyroku na sejsmologów na stronach środkowych, mniejszym drukiem. O uchyleniu wyroku prawie wcale. Okoliczność, którą wytknął Franco „Bifo” Berardi, działacz ruchu autonomistów oraz twórca radia „Alicja” w Bolonii - mianowicie że $w$ Kalifornii ofiar w ludziach nie byłoby, przy poróunywalnej sile trzęsienia ziemi, wcale - nie doczekała się dociekliwych dziennikarzy śledczych ani szerokich ech w mainstreamouych mediach.

\section{Świętoszki politycznej poprawności}

Około roku 1000 niewielu ludzi odważało się powiedzieć, że dowody na istnienie Pana Boga nie uszystkich i nie zawsze przekonują. Około 1900 roku niewielu ludzi odważało się wykazywać, że w przechodzącej rewolucję przemysłową Anglii liczba służby domowej przewyższała liczbę robotników przemysłowych. Około roku 2018 niewielu ludzi odważa się przypomnieć publicznie fakty z życia umysłowego ekologicznie nastawionych naukouców - że mianowicie ocieplanie się wód morskich nie jest aż tak szybkie, jak to naukowcy starali się wmówić politykom w trakcie poznańskiego, paryskiego albo kopenhaskiego szczytu. Dlaczego? Dlatego, że u chrześcijańskiej oraz chrystianizującej Europie mogło to doprowadzić do procesu sądowego. Dlatego, że w dostosourjącej się do przemysłowej produkcji dóbr Europie modne było solidaryzowanie się z robotnikiem ze slumsów, nie z ogrodnikiem, kucharką albo nianią. Solidarność z robotnikami mogła pomóc ich zorganizować, wyprowadzić na ulice i zmienić układ sił w parlamencie. Dlatego, że we uspółczesnym świecie każdy, kto nie kocha wieloryba, słonika albo konika, kojarzy się z osobistymi urogami Matki Ziemi. Ale nie grozi mu - niestety - proces sądowy, który przysługiwał, jak zauważa Agnieszka Kołakouska, nawet czarownicom w średniowieczu ani demokratyczna debata (trudno prowadzić debatę o znaczeniu dendrologii w życiu człowieka z przedstawicielką holenderskiej rodziny króleuskiej, która lubi obejmować drzewa w parku). Zamiast tej debaty mamy terror nie tylko ekologicznych policjantów (czego polskim przykładem jest histeria wokół ochrony przed kornikiem w Puszczy Białowieskiej), ale i gendermerii, czyli żandarmów genderowych. Jak to ujmuje wybitna polska intelektualistka, uspomniana już córka Leszka Kołakouskiego:

Na Tuitterze hasło «metoo» przesłano kilka milionów razy. Ilu czytelników miał u gazecie «Le Monde» apel Catherine Deneuve i 99 innych kobiet przypominający, że ręka na kolanie to jednak nie to samo, co guałt, potępiający wściekłą kampanię oskarżeń przeciuko mężczyznom - kampanię, na którą nie ma jak odpowiedzieć ani się bronić - ubolewający, 


\section{Sławomir Magala}

że kobiety znów są traktowane jako biedne, bezsilne ofiary a mężczyźni jako agresywne bestie, i potępiający to nowe «uyzwolenie» jako faktyczną cenzurę, która knebluje protesty, nakazuje posłuszeństwo wobec społeczno-medialnej poprawności i uszelkie głosy niezgody traktuje jako zdradę? Na pewno o wiele mniej. Ale jest równie pewne, że o wiele więcej czytelników miały obelgi wysyłane na Twitterze przeciuko autorkom tego listu. To też się nazywa postęp. I demokracja. I wolność wypowiedzi. I wolność od cenzury 5 .

Świętoszki politycznej poprawności nie są jednak święte. Polityczna poprawność umożliwia wyłącznie kosmetyczne wygładzanie wizerunku medialnego, a w dodatku na krótko - politycy, którzy się do niej uciekają, są szybko korygowani przez rzeczywistość. Problem polega na tym, że potrzebne są media, które pomagają nam zrozumieć złożoność problemów, a u polityków premiują inteligencję i uczciwość. Polega także na tym, że rachunki za błędy polityków płacą obywatele, nawet ci, zwłaszcza ci, którzy z wyborem tych polityków na stanowiska, na których mogą popełniać błędy, nie mieli nic uspólnego. Ale skąd się mamy o tym dowiedzieć, skoro polityczna poprawność święci tryumfy. Holenderska sieć sklepów HEMA postanowiła nie wieszać oddzielnie na wieszakach ubranek dla chłopców i dziewczynek, żeby nie urazić tych młodych klientów, którzy nie są peuni, czy chcą zostać chłopcami, czy dzieuczynkami. Czy Freud byłby urażony taką decyzją? Media holenderskie nie udzielają odpowiedzi na to pytanie.

\section{Bibliografia}

Berardi F. „Bifo”, AND. Phenomenology of the End. Sensibility and Connective Mutation, Semiotext(e), South Pasadena, CA 2015.

Castells M., The Rise of the Network Society, The Information Age: Economy, Society and Culture, vol. I, Blackuell, Cambridge MA \& Oxford, UK 1996.

Gleiser M., The Island of Knowledge. The Limits of Science and the Search for Meaning, Basic Books, New York 2014.

Gurri M., The Revolt of the Public (and the crisis of authority in the new millennium), Kindle Books 2014.

Kołakouska A., Fake news, corrupt media?, http://www.teologiapolityczna.pl/agnieszka-kolakouska-fake-neus-corrupt-media, s. 1 (dostęp: 22.01.2018).

\footnotetext{
${ }^{5}$ A. Kołakouska, Fake news, corrupt media?, http://www.teologiapolityczna.pl/agnieszka-kolakouska-fake-neus-corrupt-media, s. 1 (dostęp: 22.01.2018).
} 